\title{
Universiteit
}

Leiden

The Netherlands

\section{What's in it for us? Globalisation, International Institutions and the Less Developed Countries}

Kort, J.F. de; Nieuwenhuys, E.C.

\section{Citation}

Kort, J. F. de. (2006). What's in it for us? Globalisation, International Institutions and the Less Developed Countries. Neo-Liberal Gobalism And Social Sustainable Globalisation, 99-120. Retrieved from https://hdl.handle.net/1887/43252

Version: $\quad$ Not Applicable (or Unknown)

License:

Downloaded from: https://hdl.handle.net/1887/43252

Note: To cite this publication please use the final published version (if applicable). 
Source: Kort, J.F. de (2006), 'What's in it for us? Globalisation, International Institutions and the Less Developed Countries' in:

Nieuwenhuys, E., Neo-Liberal Globalism and Social Sustainable Globalisation, Koninklijke Brill NV, Leiden, 2006, pp. 99-120

\section{What's in it for us? Globalisation, International Institutions and the Less Developed Countries}

Joop de Kort ${ }^{1}$

\subsection{Introduction}

Globalisation is a relatively undefined concept. While most people have an intuitive notion of what it means, no scholarly consensus yet exists as to its form and parameters. Globalisation concerns the freeing up of the flow of trade and capital as well as the standardisation of products and production processes, and it also increasingly involves an ever more important role for international organisations. It is about making the world $a$ smaller place by ensuring quick and inexpensive transport of people and goods and, very importantly, of information.

In a broader and more politicised context, globalisation reflects the dominance of liberal economic processes over political sovereignty. It forces people all over the globe into a mode of living that renders them dependent on market transactions. It forces countries and governments to open their borders for the flow of trade and capital and to submit their trade and financial regimes to the international economic order. Within that order, the World Trade Organisation (WTO) and the International Monetary Fund (IMF) operate as a kind of a "global government". It is, therefore, not surprising that these institutions come under close scrutiny with particular regard to content of their economic policies and to the manner in which they account for these policies.

Globalisation is generally welcomed by economists who expect significant benefits from free trade and the free flow of capital. ${ }^{2}$ Anti-globalists are highly critical of the effects that unrestricted market processes have on the poor people of the world and

\footnotetext{
${ }^{1}$ I would like to thank Hans Oversloot and Eva Nieuwenhuys for comments on an earlier version of this paper. Sylvester Ryan greatly improved my English.

${ }^{2}$ Wolf, 2004 presents an excellent overview of the case in favour of globalisation.
} 
are highly suspicious of the global institutions that purportedly "govern" the world economy. ${ }^{3}$ Notably, both anti-globalists and advocates of globalisation share at least one set of similar aims, namely to provide higher levels of income and to ensure a greater welfare for the poor in the world. Yet both the sceptics and the supporters of globalisation find themselves advocating radically different policies. This is caused in good measure by their highly conflicting evaluations of the costs and benefits of free market policies. Disputes over issues related to the accountability of the WTO and the IMF arise. Antiglobalists, in particular, accuse these institutions of serving only those parties who have an interest in the broadening of the liberal economic order [i.e. rich Western countries and multinational corporations] and of denying the interests of the so-called developing countries $^{4}$ or countries in transition. Globalists, in turn, consider these institutions as guardians of the level playing field.

This essay focuses on the effects of globalisation on the developing [i.e. poor] countries, particularly with respect to both trade and finance issues where important roles are reserved for the global economic institutions - the WTO and the IMF. The WTO shapes the platform for international trade while the IMF concerns itself with international financial stability.

This essay analyses the benefits and the costs of both free trade and capital flows and will link them to the costs and benefits of relinquishing a portion of sovereignty by participation in the global economy. Further, this essay discusses the importance of economic growth to the challenge of relieving poverty as well as discusses the contributions which free trade and free capital flows can make to economic growth, especially with regard to of developing countries. The author argues that the WTO and the IMF exert a positive influence in the process of establishing the conditions for economic growth in developing countries and that participation in these institutions is the best option for developing countries to advocate and to advance their interests.

This essay has four sections. Section 2 first describes the level of development of poor countries and then critically assesses various competing strategies for economic

\footnotetext{
${ }^{3}$ Anti-globalists are far from a uniform group, but the term shelters all kinds of groups with diverging agenda's that they see threatened by the process of globalisation. Also the opposition against globalisation differs in intensity.

${ }^{4}$ There is no clear definition of developing countries. They are to be distinguished from developed countries, roughly identified with the OECD countries. A less-politically correct, but still used, term refers to these countries as less developed countries. The World Bank distinguishes between low-income, middle-income and high-income countries.
} 
growth. Section 3 concentrates on the consequences of the free trade of goods and the free flow of capital on developing countries, and Section 4 discusses the contribution of the international institutions towards the development of poor countries. Part 5 presents concluding remarks.

\subsection{The state of affairs in developing countries and their prospects}

This section discusses the degree to which poverty exists and strategies to alleviate its effects. In 1998, 1.2 billion of the world's 6 billion people lived in extreme poverty as measured as having an income of less than 1 US dollar per day. ${ }^{5}$ Almost half of the world's population, 2.8 billion people have an income of less than 2 US dollars per day. Most of these people live in Asia, China or India - each a very populous and very poor country. Yet, although the absolute numbers of poor people is still increasing somewhat, the proportion of poor people is decreasing. In this respect, East Asia is better off than other parts of the developing world in that the number of poor people in that region is declining in both relative and absolute terms. Of course, this fact correctly implies that in other poor regions of the world, such as South Asia, Latin America and Africa, the numbers are increasing. ${ }^{6}$ Overall, the difference in income between the rich and poor parts of the world has increased over time. Bourguignon and Morrisson calculate an increasing Gini-index between 1820 and 1992. ${ }^{7}$ This does not mean that the poor countries have become poorer; they actually have grown richer, but the rich countries have achieved a faster income rate of growth than have the poor ones.

\footnotetext{
${ }^{5}$ The one dollar per day is a measure, calculated by The World Bank, on the basis of income or consumption levels derived from household surveys. It actually should be a \$1.08 per day at 1993 international prices standard. It is used to identify how many people (within a country) are below the $\$ 1$ per day threshold.

${ }^{6}$ World Bank, 2000. Robert Hunter Wade, stresses the importance of China and India for these results, and notes that neither of these countries fully co-operated with the household surveys that form the basis for the globally used World Bank figures. Household surveys have large margins of errors, and the lack of good data from China and India make the poverty figures highly questionable. Poverty numbers come from household surveys, economic growth figures, however, are derived from national income accounts. Hunter Wade also questions the World Bank results on the basis of their political sensitivity, and a number of technical problems in compiling these kind of figures. Wade, 2002.

${ }^{7}$ Bourguignon and Morrisson, 2002. The Gini-coefficient is a much used measure for income inequality. Its value is between " 0 ", if everyone in the population earns the same (and thus the average) income, and " 1 " if the entire income is distributed towards a single individual, with the rest receiving nothing at all. The authors point out that 'world' inequality is definitely much bigger than 'international' inequality, as the latter one ignores income differentials within countries.
} 
However, the variance of income distribution is not just between the rich countries and the poor ones. The variance of income distribution is itself much more extreme within developing countries than within developed countries. Consider the following statistics for the 1990s: in Europe the Gini-index, was between 0.247 for Belgium in 1992 and 0.361 for the UK in 1991; in Africa, Egypt in 1995 had a Giniindex of 0.289 whereas South Africa in 1994 had a Gini-index of 0.593. Latin-American and Asian countries have also generally had a higher Gini-index than did the European countries. $^{8}$

The above mentioned one dollar per day threshold implies an absolute measure of poverty whereas the distribution of income is a relative measure of poverty. An income distribution can be unequal even when the lower income groups actually are not deemed poor according to such an absolute standard. This fact should not mean that low income people in the developed world are not to be considered poor. Poverty can also be conceived of in relative terms involving social concepts, and countries may develop their own standards for measuring poverty. The relative poverty line for developed countries would take cognisance of a greater availability of goods and services than would one for developing countries. Such consideration of the social contexts of poverty turns a discussion on the topic of poverty into a political one as much as a technical one. ${ }^{9} \mathrm{~A}$ high income growth by developing countries as compared to developed countries may narrow the income gap in relative terms but might not necessarily narrow the absolute income gap. Consider the following: A $1 \%$ increase of a 25,000 US\$ per capita income in a developed country is still five times more that of a $5 \%$ increase of a 1,000 US\$ per capita income in a less developed country in absolute terms. Thus, those people who have higher income levels also can afford greater levels of consumption.

Although generally the distribution of income is taken as the accepted instrument through which to compare rich and poor countries, the United Nations has developed an alternative approach. The Human Development Index (HDI) does not rely on income alone, but also considers other factors - life expectancy and literacy and unemployment rates. Although a number of countries have seen their index drop in the 1990s, overall

\footnotetext{
${ }^{8}$ World Bank, 2002, table 5, pp. 282-283. See also: Milanovic and Yitzhaki, 2002 and Milanovic, 2002.

${ }^{9}$ See: Ravallion, 2003.
} 
this measure shows an equalisation on world scale. ${ }^{10}$ Nevertheless, differences between the developing and the developed worlds are also found when considering such factors as life expectancy according to the HDI. Child mortality still is much higher in developing than in developed countries. $20 \%$ of the new-borns do not reach the age of 1 year in poor countries, whereas the percentage is as low as $1 \%$ in rich countries. Malnourishment rates, too, are much higher for infants in poor countries, where $50 \%$ of children under five are malnourished whereas only $5 \%$ of children under five receive too little to eat in rich countries. Life expectancy rates also demonstrate similar great differences though the gaps between the poor and rich countries in this area have been reduced. Life expectancy rates in the poor countries have increased in the recent decades most notably because of a reduction in child mortality.

As stated above, both globalists and anti-globalists are greatly concerned with the level of poverty in the world. To alleviate poverty, one option is to redirect wealth and income from the rich to the poor countries, thus distributing world income more evenly. Another popular and recently strongly advocated policy, most notably by the nongovernmental aid agencies, is debt forgiveness. ${ }^{11}$ This step in fact would constitute a large gift to the debtor countries. The author will revisit to the topic of debt relief later. Alternatively, poverty could be reduced by strengthening economic growth in the poor countries themselves to thereby raise national income. It is to be noted that debt forgiveness and economic growth are not mutually exclusive alternatives in that each strategy might enable poor countries to use export revenues to strengthen their economies rather than to service their debts.

In standard economic theory, economic growth is directly linked to investment, i.e. more investment leads to more growth. ${ }^{12}$ Investments are financed out of savings. But, in keeping with standard economic theory, since poor countries are unable to amass savings, the donor community might focus aid to bridge the so-called investment gap. ${ }^{13}$

\footnotetext{
${ }^{10}$ United Nations, 2003. The drop in the HDI is concentrated among the sub-Saharan countries of Africa and can be attributed to the widespread occurrence of HIV/AIDS in that region.

${ }^{11}$ Developing countries have accumulated huge foreign debts. In 1970, the total external debt of developing countries was 90 billion US dollars, which was $15 \%$ of their Gross Domestic Income (GDP), which has risen to 2,000 billion US dollars, or $37 \%$ of GDP, in 1998. Many developing countries have debts that are more than five times their annual export revenues. See: IMF 2000.

12 This is the very basic notion of the Harrod-Domar growth model.

${ }^{13}$ Even if Domar, in 1957, disavowed his theory, it has been used continuously in International Financial Institutions to underpin investment aid. See: William Easterly, 2001: pp. 28-29. It has further to be noted that the Harrod-Domar
} 
Developing countries would in turn benefit from investments in the latest, most productive, technologies in order to close the income gap with developed countries.

However, thus far all the aid that has been flowing to the developing countries has not reduced the income gap with the rich world. Growth in the poor countries has been slow and even negative in some cases. Of course, it is debatable whether aid has been used productively in investment as opposed to mere consumption, but studies that have compared investment to growth find no association between predicted and actual growth using the income gap approach. ${ }^{14}$ Furthermore, the benefits of investment in new technologies flow to the developed rather than to developing countries.

More recent contributions to economic growth focus on investment in knowledge. Under some approaches, knowledge itself is treated an economic asset, albeit a special one in that new knowledge does not replace old knowledge, but rather builds on or complements previously acquired knowledge. A new software programme, for instance, increases the productivity of existing IT technology without much investment in new IT. Similarly, software building firms can benefit from the pool of available knowledge by locating to an area where other software firms are already present. Such actions contribute to the formation of flexible labour markets to cite one of the benefits. ${ }^{15}$ Furthermore, knowledge, as opposed to tangible capital, has the characteristics of a so called public good. ${ }^{16}$ Knowledge produces increasing rather than decreasing returns - this makes it an attractive investment. But the return on such an investment is highest when knowledge is already available. A major problem for developing countries is brain drain. Their bright and educated people tend to pursue careers in the developed countries where they can be more productive and earn higher incomes. Thus, developing countries are left with an ever narrowing knowledge base out of which to make investments attractive and profitable.

model essentially was a model for the short run business cycle, rather than for macro-economic growth. The debt forgiveness initiative actually is similar in its approach. Rather than spending the export revenues on debt servicing, they be spend investing.

${ }_{14}$ William Easterly, 2001, pp. 43-44.

${ }^{15}$ The concentration of production also benefited many of the more traditional industries, with opportunities to outsource maintenance, to further specialisation, to exchange new processes quickly among others. This is known as economies of scale and helps to explain why many industries are concentrated in a few locations, Lancashire for textiles, Detroit for cars, Silicon Valley for IT to name a few.

${ }^{16}$ A public good has two main characteristics: the consumption of the good by one individual does not restrict others from consuming that same good; neither does its availability diminishes. 
To make matters worse, new technologies render old ones obsolete, hence worthless. Computers have replaced typewriters, desktops have replaced mainframes and laptops increasingly replace desktops. New industries replace old ones because the old industries fail to compete in terms of efficiency and costs. When investments in new knowledge primarily benefit the developed world, the developing countries end up with a larger share of the older and obsolete industries. This, too, contributes to the increasing level of income inequity in the world. ${ }^{17}$

Another important aspect of globalisation is the freeing up of the flow of capital. Yet this, too, can increase the problems the developing countries in that capital tends to flow in search of higher returns towards the developed countries. On the other hand, the trade base of the less developed countries has broadened. They are less dependent on the export of natural riches and agriculture for their export revenue. The share of manufacturing in the total export of low income countries increased from $20 \%$ to $80 \%$ over the past two decades. ${ }^{18}$ Despite this, these low income countries are still rather vulnerable in that their export bases are much smaller than those of most developed countries. As will be discussed in the next section, whether or not the developing countries will actually benefit from increased participation in the global economy is yet to be determined.

\subsection{Do free trade and free capital flows benefit developing countries?}

The supporters of globalisation give much credit to free trade as a cause for economic growth. The traditional argument for free trade builds on the concept of comparative advantages. The relative abundance of labour in poorer developing countries makes them attractive for the production of, and investment in, labour intensive products whereas the

\footnotetext{
${ }^{17}$ Old technologies often function very well in developing countries. Mechanical typewriters do not require steady current to operate and do fine to fill in paper forms to file taxes, to request permits and so on. High tech may be needed to compete in the world markets, but cheaper and reliable low tech solutions may be profitable to operate in developing countries as well and thus contribute to economic development.

${ }^{18}$ World Bank, 2003, pp. 66-67. The schism between East Asia and the other regions with poor countries reappears with respect to the participation of the countries in the world economy. Overall, the share of the developing countries in world exports has been increasing in the past two decades, but this increase can be attributed to East Asia; the shares of Africa and Latin American exports in world exports actually have decreased. See: Cernad, Laird and Turrini, 2003, pp. vi-vii.
} 
abundance of capital makes the developed countries attractive for the production of, and investment in, capital intensive products. However, trade patterns can only be partly explained by looking at comparative advantages. First, trade is very much a regional matter in that countries that are geographically near to one another tend to trade more. , For instance, $25 \%$ of total world trade is between the countries of the EU. Similarly, the USA, Canada and Mexico, partners in NAFTA primarily trade with one another. ${ }^{19}$

Outside this regional component of world trade, the rich countries tend to trade with one another. The EU, the USA and Japan are important trading partners. The large trade flows between the developed countries leave the poor countries sidelined in the world of global trade. ${ }^{20}$ There are changes to be noted, however. Especially since the 1960s when multinational firms started to increasingly use multi-country sourcing. Production processes within industries have become partitioned giving rise to trade. Nowadays, very few industrial products are produced entirely within a single country. Parts come from different places, and the assembly process itself also often is split among various locations. This practice gives rise to large trade flows mostly between the industrialised countries. As with the knowledge industry, and to an extent due to superior levels of know how, many industries enjoy increasing returns of scale through such practices. ${ }^{21}$ The developed world has turned into a very integrated industrial economic system that is gradually including developing countries into its web of interdependencies.

Comparative advantage and economy of scale, the theoretical arguments raised in favour of free trade, are both comparatively static by nature. The new end situation produces better results than the old starting situation. Opening an economy, however, is a very dynamic process, which may take on its own dynamics. Empirical studies, however, confirm a positive link between openness and economic growth. ${ }^{22}$ But again, the Asian countries dominate this effect. In the 1970s, they opened their economies and started to

\footnotetext{
${ }^{19}$ WTO, 2002, pp. 22-23.

${ }^{20}$ The World Bank points to the benefits that developing countries can reap if they lower trade barriers themselves, which would create opportunities for trade among developing countries. See e.g. World Bank, 2003.

${ }^{21}$ Increasing returns to scale can be either external, with the benefits falling upon the industry as a whole, or internal, with the benefits appropriated by individual firms. The external returns explain the concentration of industries, like the before mentioned textiles in Lancashire, or software in Silicon Valley and trade is needed to export products from those regional concentrations. Internal returns may give rise to industrial policies in developed countries to help a firm to acquire the necessary scale to be competitive in the world market, that an only support a few firms. A classic example is to be found in the world market for large aeroplanes. It is either Boeing or Airbus in that market.

${ }^{22}$ Nordström, 1999 for a list of studies. See also World Bank, 2002.
} 
grow. Similarly, India recently lowered its import barriers and is showing signs of growth as well. At the same time, closed economies remained behind in the growth statistics.

This does not mean that free trade only has winners. Opening up an economy will result in changes in the price structure in a particular economy and, hence, to trade flows in and out of that country, which in turn will lead to changes in the prices and distribution of the factors of production. The wage differential between the skilled and the unskilled will increase as trade liberalisation reduces demand for unskilled labour because higher levels technology will be introduced. ${ }^{23}$ This may cause insurmountable problems for large groups in society that find themselves losing their means of existence. And, in some cases it may be either impossible or too time consuming to develop or find alternatives. Poverty leaves little time to invest in retraining. In this respect, a classic problem in development arises where new production methods not only provide higher revenues, but also require new ways of production and, therefore, lead to a clash of cultures and other problems involving social costs. ${ }^{24}$ Changes in the price structure may also change the real income distribution. Furthermore, if an economy is opened through the lowering or abandoning of import tariffs, the government of that country will lose tariff revenues, and will have to find other means to finance expenditures. Developing countries, however, often have large informal economic sectors and a poor fiscal administration and, therefore, have difficulties collecting taxes. ${ }^{25}$

An important argument with respect to the success or failure of poverty reduction resulting from free trade revolves around the development of the terms of trade. This relates the changes in the price structure due to international trade. Developing countries export relatively simple industrial products and import more sophisticated products. The prices of their exports tend to experience downward pressure, whereas their imports become more expensive. A recent trend in this respect is the increased trade in services which confirms the price ratio of trade between developing and developed countries. This worsening of the terms of trade makes it more difficult for developing countries to catch

\footnotetext{
${ }^{23}$ Agenor, 2002. See also Ravallion, 2003

${ }^{24}$ Coase, 1960, analyses the dilemma of the imposition of burdens as a result of changes. His problem was that if B was not allowed to harm A, it was the same as A harming B. His was a pricing solution, to offset the damage, but traditional values are difficult to put into an economic pricing schedule.

${ }^{25}$ See Winters, 1999, for a checklist of 11 key questions regarding the distributive effects.
} 
up with developed countries just as it makes it more difficult for them to earn sufficient export revenues to service their debts. ${ }^{26}$

Although capital flows were already increasing since the 1960s, their real expansion started in the 1980s. ${ }^{27}$ Trade flows continued to increase, which raised demand for the financial instruments which facilitate trade. Production processes were moved around. The European Communities started to prepare for a single market, and many countries tried to attract foreign investments. These changes had further ramifications.

Many of the capital flows are merely financial flows only and do not lead to foreign direct investment. ${ }^{28}$ The trouble with these flows is that problems that appear anywhere in the financial system will quickly lead to massive displacement of financial funds, and at least several consequences in the macro-economic monetary system of a particular country will ensue in the form of changes in the interest rate, the rate of inflation, and the exchange rate. The interconnected nature of each element of the international capital markets causes maladies in one part of the system to quickly spread to other parts of the system. ${ }^{29}$ As with trade flows, it has to be noted that the bulk of the capital flows is between developed countries and show a similar pattern as do the trade flows - the USA absorbs most of the foreign investments to finance their huge current budget deficits. $^{30}$

As was mentioned above, with respect to developing countries a free flow of capital should contribute to economic growth in that it allows capital to seek the highest returns. Such a capital flow should augment domestic savings in developing countries, and such increased availability should reduce the cost of capital. As with trade, freeing

\footnotetext{
${ }^{26}$ See for example: Wade, 2002, or Birdsall, 2002.

${ }^{27}$ Multinational corporations used transfer pricing on their internal trade as a means to transfer capital. The eurodollar market emerged in the 1960s too.

${ }^{28}$ Foreign direct investment ties capital up in physical units and includes a direct management involvement with use. It generally cannot be taken out swiftly. It are these investments rather than the financial investments that are refered to in the relationship between investments and economic growth.

${ }^{29}$ More than 95 percent of all countries in the world, still impose restrictions on capital flows in one way or another. Foreign direct investments and commercial bank transactions are among the activities subject to most restrictions. See: IMF, 2002. The Asia crisis in 1997 showed that even generally sound and solvable countries can run into liquidity problems and suffer from a financial crisis. See e.g. Eichengreen, 1999, or Haggard, 2000. Interestingly, emerging markets, more than the traditional debtor countries, suffered from financial crises in the 1980s and 1990s, as their debt was private debt. Most debt in developing countries is to governments of developed countries and to the international organisations, which is shielded from the volatile capital markets more than private debts. In case of the Asian countries that were hit by the financial crisis in 1997, most of them have rebounded very quickly. The most notable exception being Indonesia that went from bad to worse after the financial crisis revealed a fundamentally weak and distorted economy.

${ }^{30}$ IMF, 2002b.
} 
capital flows creates bigger markets, leading to increased competition and a better result overall. Trade and finance integration basically go hand in hand. They are related to the same factors, and supplement one another. Countries that are trade integrated do not suffer as severe financial crises as do countries that are more closed to trade. Similarly, countries that are more open to investment suffer less from output volatility, though this is mainly realised over the longer run. ${ }^{31}$

The benefits of financial integration, however, are less clear than those of trade integration. There is no robust empirical proof that financial integration has a positive effect on growth for instance. ${ }^{32}$ Furthermore, developing countries are very vulnerable to volatile shocks, which may harm their economies. Typically, they have weak financial institutions, and their capital markets are not very deep and do not offer a wide array of choices through which to diversify financial investments. Their currency is not fully accepted as a reliable vehicle of value. They often rely on fixed exchange rates to provide an anchor and fear floating their currency. The combination of these characteristics results in the absence of markets for local currencies, for long-term domestic currency denominated finance and for hedging derivatives which increases a country’s vulnerability to financial crises. ${ }^{33}$ On the positive side, that same vulnerability makes developing countries less attractive for investments in financial assets, and consequently the liberalisation of capital flows to a great extent passes them by.

\subsection{The contributions of international economic institutions}

Capital markets are not just characterised by a high level of volatility leading to vulnerability of developing countries. Information asymmetries are becoming an important issue as well. The increased importance of capital markets in (international) business and the need to protect investors have induced the equity markets to strengthen rules and regulation. Businesses are forced to disclose information on their operations, their plans, their assets and their liabilities on an annual and, increasingly, a quarterly basis. This helps financial investors to assess the risks and prospects of their investments

\footnotetext{
${ }^{31}$ Fingerand and Schuknecht, 1999. Also: IMF, 2002c, Chapter 3.

${ }^{32}$ Prasad, Rogoff, Wei and Kose, 2003.

33 de la Torre, Yeyati and Schmukler, 2002. See also: Pierrre-Richard Agénor, 2002.
} 
in specific firms. Investments with higher risks have to pay a higher premium. This mechanism provides an incentive for business to disclose much of their financial information. ${ }^{34}$ The importance of transparency and good governance are being stressed in studies on the capital markets and these concepts increasingly find their way into the economics of development and into the policies that govern aid. ${ }^{35}$

Developing countries often do not meet investor requirements, a fact that makes investors hesitant to commit themselves to activities in these countries. This hurts their chances for development. Thus, development and debt forgiveness programmes recently emphasise good governance and good economic policies very heavilly. One important programme in this respect is the Heavily Indebted Poor Countries Debt Initiative (HIPC) that runs under supervision of the IMF and the World Bank. This 1996 initiative aims to reduce the debt burden of eligible countries to levels that they can manage. This would allow them to invest in productive activities. ${ }^{36}$ To be eligible for debt relief under the HIPC Initiative, a country first needs to establish a track record of three years of commitment to the reduction of macro-economic imbalances and sustainable growthoriented policies. During this period, the Paris club creditors provide a debt rescheduling. ${ }^{37}$ The pre-condition of a strong policy performance is put in place because debt in general is only one of the problems facing developing countries. Fulfilment of the pre-conditions help to establish a situation in which countries can rely on financial markets to finance those credits or investments which they might wish to finance under standard conditions. A debt sustainability analysis, conducted at the end of three years, establishes whether a country is in a sustainable external debt position. If it is, the Paris club rescheduling is completed, and an indebted country is eligible for debt relief. If it is

\footnotetext{
34 The most attractive exchange for business, the New York Stock Exchange, has the most far-reaching disclosure rules. Being quoted at the NYSE, however, gives companies access to more and cheaper capital.

${ }^{35}$ See for an important contribution Burnside and Dollar, 2000. According to William Easterly, this paper has been 'adopted' by the international aid agencies to provide the argument to provide aid only conditional to good governance. Easterly, with others, replicated this study with data that after its publication has become available and find no support for the conclusion that aid works in a good policy environment. Easterly, 2003.

${ }^{36}$ Sustainable levels of debt are defined as debt to export ratio in a range of 200-250 percent, a country needs more than twice its total export revenues for a year to pay off its entire debt, and a debt service to exports ratio of 20-25 percent, a country is expected to be able to spend close to a quarter of its export revenues to honour its redemption and interest obligations on its debt. For very open economies (with an export to GDP ratio of at least 40 percent), the criterion that the ratio of debt to government revenues should exceed 280, a country would need almost three times its annual revenues to pay of its debt. See: Boote and Thugge, 1997.

${ }^{37}$ The Paris club unites creditor countries and discusses sovereign debt rescheduling. This may include debt reductions up to 67 percent. There also exists a so-called London club, which unites private creditors, banks and other financial institutions for the same purpose, rescheduling debts.
} 
not, the country a second three year period in which further debt rescheduling on more favourable terms is enacted. If a country establishes an extended track record, up to 80\% of its debt may be cancelled.

An important feature of the HIPC Initiative is the inclusion of all creditors in the debt rescheduling. Bilateral, multilateral and commercial creditors are supposed to work together, each assuming some of the costs of writing off debt. This collective action aims to prevent free riding and a subsequent higher burden for some of the creditors. This system acknowledges that the debt problem is a collective problem both for debtors and creditors. An individual debtor (an indebted country) has to prove ‘ownership’ of the program and has to go through the effort of including commercial creditors in the program. ${ }^{38}$ Debt relief through the HIPC initiative, US\$ 51 billion, is not supposed to substitute other aid. The IMF finances its share of the relief through the proceeds from off market gold sales that are put in a trust. Member countries also have to add contributions to this trust.

In 1999, in response to critiques over its strict conditions, an enhanced HIPC initiative enabled lower thresholds to be applied to the measure of eligibility, for less strict adherence to the 6 years period intended to establish a track record and for changes in the assessment base among other matters. ${ }^{39}$ Other modifications included faster and broader debt relief and the inclusion of a Poverty Reduction Strategy Paper. This Paper is intended to strengthen the link between debt relief and poverty reduction and to anchor debtor commitments. ${ }^{40}$ Although the Initiative provides debt reduction to 27 countries, in the amount of US\$ 51 billion over time, it has been criticised by non-governmental organisations that argue that the HIPC initiative still does not accomplish what it is supposed to do and that the IMF is too rigid in its policies. ${ }^{41}$ Developing countries, even after completion of the initiative, continue to have unsustainable debts. Both economic as well as export projections turned out to be too optimistic, and poor countries were more vulnerable than anticipated with regard to, for instance, developments in neighbouring

\footnotetext{
${ }^{38}$ For example, the debtor country can buy back some of its outstanding commercial debts at a discount.

${ }^{39}$ The debt to export ratio was lowered to 150 from 200-250, while the debt to fiscal revenue ratio was put at 250, from the original 280. The export to GDP ratio fell from 40 to 30 .

${ }^{40}$ Andrews, Boote,,Rivazi and Singh, 1999.

${ }^{41}$ See, e.g. Pettifor, Thomas and Telatin, 2001 or: Oxfam, 2003.
} 
countries and changes in their terms of trade. ${ }^{42}$

Reflecting in the HIPC initiative at a more general level, the IMF is accused of operating undemocratically and, according to some critics, in the interests of the developed countries. ${ }^{43}$ The position of the IMF, however, is a special one. It was intended at its creation in 1944 to offer short term credits for countries that faced temporary deficits in their balance of payments. All members were deemed 'equal' because today's debtors might become tomorrow's creditors, and the creditors of today might one day have to rely on IMF credits in the future. However, since the demise of the initial IMF framework in the early 1970s, the IMF increasingly became involved in structural debt financing. However, today's debtors are likely to be the same as tomorrow's debtors, and it is rare for a creditor to become a debtor. The IMF, therefore, finds itself in a position of a bank attracting funds (savings) from rich countries, and extending credits to poor countries. The IMF performs a delicate balancing act. Although formally ruled by its articles of agreements, its capital is insufficient to offer all the requested assistance. It therefore has to raise additional credits, subject to terms to be negotiated by the providers of the credit. The IMF act then as the middleman between debtors and creditors. Nonetheless the IMF is owned by rich and small countries alike. ${ }^{44}$ Like banks, the IMF works with loans rather than with equity to finance its activities and is vulnerable to defaults and accountable to its creditors. In the case of the IMF, its outstanding credits ultimately are financed by taxpayers in the creditor countries. Running the debt programs through the IMF, however, relieves governments of creditor countries from having to go through their respective parliaments to free up money in their budgets. This increases the speed with which IMF programs can be installed, but it reduces the accountability of the ministries of finance of the creditor countries towards their constituencies. It depoliticizes debt relief programs. Not to put the finance ministers in an awkward situation towards their parliaments, the IMF, therefore, needs to be a reliable debtor, a fact which is

\footnotetext{
${ }^{42}$ The Jubilee report for instance point to the anti-smoking campaigns which hurt tobacco producing and exporting countries; the rise of Viet Nam as second coffee exporter of the world contributed to a downward trend on the coffee prices.

${ }^{43}$ Pettifor, 2001, p.16, argues the need to transform the international financial architecture, that will introduce a transparent debt negotiation process, accountable to citizens in both debtor nations and creditor nations.

${ }^{44}$ Voting powers in the IMF are distributed according to the respective shares of countries in the capital of the Fund. The USA on this account owns 17.14 percent of the votes, the Netherlands owns 2.39 percent, and Malawi owns 0.04 percent. See IMF website.
} 
reflected in the conditions it imposes on the debtor countries. The IMF, for instance, is always a preferred creditor - that is, the first in line for debt settlement. This, of course, puts high pressure on the debtor countries.

The criticism which is applied to the other major international economic institution, the WTO, is similar to that with respect of the IMF. The WTO is accused of acting predominantly in the interests of the developed countries. As opposed to the IMF, the WTO is not turned to in times of crisis. Nor does the WTO disburse money. The WTO is a nexus of rules with respect to trade more than anything else. These rules were created in a series of trade rounds between 1949 (Annecy) and 1994 (Uruguay) under the auspices of the General Agreements on Tariffs and Trade (GATT) which in 1995 was eventually transformed into the WTO. Initially, the trade rounds were concluded among the countries of the developed world. Gradually, the number of member states increased to 148 to include many developing countries at the end of 2004. To become a member, countries have to adhere to the rules. Adapting domestic rules and regulations to conform to the WTO often incur costs for new members as also might the ensuing economic situation. Countries may have to forfeit custom duty income for example. ${ }^{45}$ To a greater degree than the traditional removal of trade barriers and the subsequent lowering of tariffs, the more recent additions of Trade Related Investment Measures (TRIMs) and Trade Related Intellectual Property rights (TRIPs) to the WTO framework, force members into a globalised and uniform set of rules. TRIMs and TRIPs were originally pressed by developed countries to further the interests of their industries, and the developing countries are basically forced to accept them. ${ }^{46}$ The WTO, however, does allow a period of transition and provides assistance to the implementation of its rules and regulations. Furthermore, developing countries also receive assistance with regard to participation in the Dispute Settlement Mechanism, which serves an important function within the WTO. ${ }^{47}$ The most offensive issue to developing countries with regard to WTO, one that is shared both by anti-globalist and advocates of globalisation, involves two areas in which the developing countries are perceived to have a comparative advantage -

\footnotetext{
${ }^{45}$ This is not an unimportant issue for many developing countries that do not have sophisticated tax systems and rely on custom duty incomes for government expenditure to a greater extend than do developed countries.

${ }^{46}$ Finger, 2000. See also: Hoekman, Mattoo and English (eds.), 2002.

${ }^{47}$ The Netherlands, for example, pays for legal assistance that developing countries require to bring or defend cases for the Dispute Settlement Mechanism.
} 
agriculture and textiles. The developed countries refuse to open up their own markets for these goods to the developing countries. Further, within the WTO framework a corresponding inability to force acceptance exists. This ensuing stalemate results in the denial of the possibility of generating major export revenues needed by developing countries. $^{48}$

Overall, not surprisingly these international economic institutions have a bad reputation. The IMF imposes strict conditions on developing countries, and the WTO rules seem predominantly to benefit developed countries' interests. Notwithstanding the dominance of the developed world in the IMF and the WTO, an important question is whether the developing countries would be better off without them and whether these institutions can be transformed into more equitable ones.

Regarding the latter issue, the failures of the WTO meetings in Doha and Cancun prove that the balance of powers in the WTO is amendable. Within the WTO, consensus is an important way to attain agreement. A coalition of 21 developing countries with varied individual interests was able to build such a consensus to force the agenda into their direction. Developed countries, most notably the USA and the EU states were unable to play countries off against one another and were unwilling to accommodate the wishes of the coalition. The failure of the Cancun meeting signals a change in power balance. Unfortunately, it could be a Pyrrhic victory for the group of developing countries. The meeting in Cancun was but a progress meeting in the Doha round which has been only the first such round that recognized poverty reduction as an explicit goal. The failure of this meeting provides developed countries with yet another excuse to postpone trade liberalisation in agriculture. It furthermore may induce these developed countries to attempt to bypass the WTO system and alternatively to undertake bilateral trade agreements whose terms might be more favourable to their interests. ${ }^{49}$ Such a strategy may benefit some developing countries, but surely will hurt others. A further indication that developing countries are to some extent affecting the balance within the

\footnotetext{
${ }^{48}$ Here again, it is good to note the importance of lowering trade barriers in the developing countries themselves to allow opportunities for trade among another. See also footnote 20.

${ }^{49}$ The minister of Economic Affairs of the Netherlands, L.J. Brinkhorst, in a reaction to the failure of the Cancun meeting, stresses the importance to prevent a shift towards bilateralism away from a multilateral approach towards free trade. See: Brinkhorst, 2003.
} 
WTO is their increased use of the Dispute Settlement Mechanism. ${ }^{50}$ Such a shifting of power with regard to the present balance is less likely within the context of the IMF where developing countries truly occupy a more dependent position. Outside of the context of the IMF heavily indebted countries would find themselves without access to capital markets and thus with no means at their disposal at all to finance development initiatives. These countries simply need credit, and the developed countries often are able to direct the use of IMF approvals to disburse aid or credits.

The modern development of the European and American economies predates the creation of these global economic institutions, so strictly speaking there is no need for these institutions to establish economic growth on a global basis. The world economy, in fact, was arguably more open in the $19^{\text {th }}$ century, than during most of the $20^{\text {th }} .{ }^{51}$ Since 1944 when the IMF, the World Bank and GATT were created, ${ }^{52}$ they have been credited for having contributed to the increased openness in the world economy and to a long period economic growth. They have offered an institution which provides the forum for collective action and have prevented the reoccurrence of the beggar thy neighbour policies of the interwar period which are believed to have contributed to the depth and longevity of the economic crises which fostered the outbreak of the war. Membership in both the IMF and GATT, as is characteristic of all international agreements, create dilemmas over questions of jurisdiction. For example, until 1973 the IMF required its member states to maintain fixed exchange rates and capital controls, and GATT requires participating countries to lower their tariffs across the board and not to discriminate between the various GATT signatory states. Upon becoming members and parties to such international institutions, states no longer have the freedom to act over policy issues falling to those institutions. Consequently, questions arise concerning how those international institutions make their decisions.

Both institutions are careful to deflect criticism. The WTO, as the legitimate

\footnotetext{
${ }^{50}$ A count of the disputes at the WTO website reveals that one third of all cases in the twenty-first century are brought by developing countries, In the twentieth century this was less than a fifth. The Dispute Settlement Mechanism was introduced with the creation of WTO in 1995.

${ }^{51}$ See for instance: Peck, 1983, or: Maddison, 1989.

52 The IMF, World Bank and the International Trade Organisation (ITO) were created in 1944.The slow ratification process with respect to the ITO lead 21 countries to advance trade liberalisation through an General Agreement of Tariffs and Trade (GATT), which was signed in 1947. This Agreement resulted in extensive reductions of tariffs and liberalisation of trade. The agreement expanded to about 120 members that during the so-called Uruguay round of talks (1986-1994) decided to create the World Trade Organisation.
} 
successor of GATT makes a great point of its consensus rule and its subordinate position to its members. The IMF too, mentions its accountability to its 184 shareholders and stresses that policy decisions and matters which impact the various countries are made by consensus. It also points out that developing countries as a group represent about 37 percent of the vote on the Executive Board of the IMF. And the IMF further points to the importance of the financial contributions that the IMF needs to carry out its policies, i.e. to function in the international financial system. Formal positions do not, however, accurately reflect the real situation.

One situation involves the challenge of getting the attention of these institutions. Consider the following example: These institutions may be accountable to governments, but how can interest groups, in all their diversity, manage to have their voices heard and to get their points onto the international economic agenda? Traditionally, such interest groups would address their concerns to national governments, but these have already transferred some of their policy discretion to the international organisations. Interest groups thus are bounced between these international organisations and national governments. $^{53}$

To their credit, both the IMF and GATT have demonstrated an increased openness towards their critics as well as a higher degree of accountability towards the general public. Their websites provide a wealth of discussions and positions with regard to their policies. They demonstrate an awareness of the nature of the criticism about their policies and produce many papers which address the issues raised.

From a global point of view the transfer of sovereignty may also benefit nations and interest groups. Countries that might on a unilateral basis decide even through the democratic enactment of a rule that introduces tariffs in order to protect its own industries would harm the development of industries in other countries. The transfer of sovereignty to international organisations curbs this likelihood and ensures that other countries have

\footnotetext{
${ }^{53}$ Rodrik, 2000, describes this as a trilemma where you can have three situations. The golden straitjacket allows nation states to benefit maximally from integrated economies by harmonising all domestic regulations and tax policies to pose no hindrance. This restricts access of interest groups to national economic policy making. Global federalism bypasses national states and remove borders. There would in fact be a global government and special interests can be directly directed at the global government. Finally, the Bretton Woods compromise (the IMF, World Bank and the ITO were created in Bretton Woods) sacrifices complete economic integration and restores national sovereignty and introduces a rather loose set of compromises in trade and finance. It leaves special interest groups guessing where to state their case, at national governments or at the international economic institutions.
} 
the opportunity to advocate their case when such situations arise. ${ }^{54}$

With regard to the relief of poverty, the requirements of membership and the preconditions required in order to receive credits may be perceived as paternalistic and even undemocratic. Still, they also may be the most effective way to make progress towards achieving the goal of relieving poverty. Critics might complain that the credit ratings of poor countries often are low and that these countries have accumulated large debts because their governments over a period of time have bad track records in government finances as well as investor protection. And critics can further point out that corrupt officials are able to siphon off much of the funds, aid or credit before it reaches the poor. ${ }^{55}$ Bur, undeniably membership in international economic institutions helps strengthen the institutionalisation that fosters economic growth, and it offers an opportunity for poor countries to participate to some extent in development of international policies. It would be naïve to ignore these institutions. With or without them, the internationalisation of economic life exists, and sovereignty is already compromised and eroded. ${ }^{56}$

\subsection{Concluding Remarks}

This article, having surveyed the literature on globalisation, argued that poverty is a relative notion and can be addressed from a policy standpoint through either income distribution or economic growth. The author has argued that income distribution is politically a highly sensitive issue which directly relates to the level of solidarity between members of society. Economic growth raises total income in a country and, hence, creates the opportunity for everyone to be better off than before. Nonetheless, further consideration the distribution of income must remain a topic of discussion. Economically, a relationship does exist between the distribution of income and economic growth, but the nature of that relationship is yet to be clarified.

This essay also analysed the competing economic theories of development.

\footnotetext{
${ }^{54}$ This is a similar case as is discussed by Coase, 1960. Roustiala, 2003, explicitly discusses this point.

${ }^{55}$ Developing countries generally score very low on Transparency International's Corruption Perceptions Index. Transparency International, 2003, p.12. William Easterly, 2001, discussing the effectiveness of aid concludes that little research is performed to measure his effectiveness, and that even when it is concluded that aid does not reach its targets, it rarely is revoked or stopped

${ }^{56}$ Kal Roustiala, 2003, p. 875.
} 
Traditional policy recommendations for economic growth, which originated from the investment gap approach, have for a number of reasons failed to close the gap between the rich and the poor countries. The more recent approaches to providing development aid still recognise the importance of investments as a driver for growth. The call to forgive large portions of poor countries' debts is proof of that point. Debt relief allows developing countries a fresh start. The more recent approaches to development, however, contrast with the traditional in that they stress the standard economic benefits of comparative advantages both with regard to trade and finance. These approaches strongly advocate free trade, and their proponents point to the impressive growth performance of countries that have opened up to the world markets, most notably China, India and several other Asian countries. These results, however, have not gone unchallenged. The means by which actual growth is measured raises highly contentious issues, and critics note that the distributive effects of opening up an economy may disrupt its economic structure. Very recently, great interest has been focussed on the notion that more attention should be paid to the roles played by institutions and proper governance. This rapidly spreading approach supports a role for international institutions such as the IMF and the WTO. In the HIPC initiative, the IMF links debt relief to proven policy performance, whereas the WTO institutes a set of trade rules and provides a dispute settlement mechanism to prevent the need to struggle for mere survival in an unregulated global economy. Although the democratic values of these institutions are subject to both political and legal discussions, the author argues that from an economic viewpoint these institutions help to provide opportunities that can benefit developing countries. They operate according to transparent articles of agreement and rules of conduct.

Despite the benefits offered by the international economic institutions, developing countries should not turn their fates over unconditionally. As just mentioned, the global economic system may well bring new problems for them as well. Creating a level playing field, as runs the modern expression, does not necessarily benefit the weaker players, and developing countries undoubtedly are the weaker players in the international economic field. Nonetheless, the option of not participating is limited and will most likely not 
advance economic growth in the countries that take such a route. ${ }^{57}$ The international institutions, on the other hand, offer a forum where the consequences of asymmetrical relations can be discussed with all participants at the table, and the developing countries have shown their ability to state their interests and change policies.

\section{References}

Agent 2002

Pierre-Richard Agent, Does Globalisation Hurt the Poor? WB draft paper, version sept. 92002

Andrews, Boote, Rivazi and Sing 1999

David Andrews, Anthony Boote, Syed Rivazi and Sukhwinder Singh, Debt Relief for Low-Income Countries. The Enhanced HIPC Initiative, IMF, pamphlet Series, No. 51, 1999, see IMF website

Birdsall 2002

Nancy Birdsall, A Stormy Day in an Open Field: Asymmetry and Convergence in the Global Economy, in: in: D. Gruen, T. O’Brien and J. Lawson (eds.)

Globalisation, Living Standards and Inequality. Recent Progress and Continuing Challenges. Proceedings of the RBA Annual Conference, Volume 2002.

Boote and Thugge 1997

Anthony Boote and Kamau Thugge, Debt Relief for Low-Income Countries and the HIPC Initiative, IMF WP/97/24.

Bourguignon and Morrisson 2002

Francois Bourguignon and Christian Morrisson, Inequality Among World Citizens: 1820-1992, American Economic Review, 2002, Vol 92, No. 4 pp. 727 744 ,

Brinkhorst 2003

L.J. Brinkhorst, Hoe verder na Cancún?, Internationale Spectator, November 2003, LVII, nr. 11, pp. 524-526.

Burnside and Dollar 2000

\footnotetext{
${ }^{57}$ This of course would be a legitimate choice, but one that requires a firm closing of the economy and a high level of centralisation of trade, such as the former communist countries experienced.
} 
Craig Burnside and David Dollar, Aid, Policies and Growth, American Economic Review, volume, 90 no 4, summer 2000, pp. 847-868.

Cernad, Laird and Turrini 2003

Lucian Cernad, Sam Laird and Alessandro Turrini, Back to Basics: Market Access Issues in the Doha Agenda, UNCTAD, 2003.

Coase 1960

Ronald Coase, The Problem of Social Cost, Journal of Law and Economics, 1960, Vol. 3, pp.1-44

Easterley 2001

William Easterly, The Elusive Quest for Growth. Economists'Adventures and Misadventures in the Tropics, Cambridge MA, MIT press, 2001

Easterley 2003

William Easterly, Can Foreign Aid Buy Growth? Journal of Economic Perspectives, summer 2003, volume 17, no. 3, pp. 23-48.

Eichengreen 1999

Barry Eichengreen, Toward a New International Financial Architecture. A Practical Post-Asia Agenda, Washington, IIE, 1999

Finger 2000

J. Michael Finger, The WTO's Special Burden on Less Developed Countries, Cato Journal, 2000, Vol. 19, no 3, pp. 425-437.

Fingerand and Schuknecht 1999

K. Michael Fingerand and Ludger Schuknecht, Trade, Finance and Financial Crises, Special Studies 3, WTO, 1999

Haggard 2000

Stephan Haggard, The Political Economy of the Asian Financial Crisis, Washington, IIE, 2000

Hoekman Mattoo and English, 2002

Bernard Hoekman, Aaditya Mattoo and Philip English (eds.), Development, Trade, and the WTO. A Handbook. The Worldbank, 2002

IMF 2000 
IMF, World Economic Outlook, Asset Prices and the Business Cycle, p. 137, May 2000.

IMF 2002 (a-c)

IMF, Exchange arrangements and Foreign Exchange Markets, 2002a, via website IMF, Global Financial Stability Report, September 2002b, via website.

IMF, World Economic Outlook, 2002c

Maddison 1989

Angus Maddison, The World Economy in the 20 ${ }^{\text {th }}$ Century, Paris, OECD, 1989.

Milanovic and Yitzhaki 2002

Branko Milanovic and Shlomo Yitzhaki, Decomposing World Income Distribution: Does the World has a Middle Class, Review of Income and Wealth, Series 2002, 48, No 2, pp.155-178

Milanovic 2002

Branko Milanovic, True World Income Distribution, 1988 and 1993: First Calculations based on households surveys alone, The Economic Journal, 2002, Vol. 112, pp. 51-92

Nordström 1990

Håkan Nordström, Trade, Income Disparity and Poverty: An Overview, WTO, Special Studies, 5, 1999

Oxfam 2003

Oxfam, The IMF and the Millennium Goals. Failing to deliver for low income countries, Oxfam Briefing Paper, 54, 2003.

Peck 1983

James Foreman Peck, A History of the World Economy. International Economic Relations since 1850, Brighton, Wheatsheaf, 1983

Pettifor, Thomas and Telatin 2001

Ann Pettifor, Bronwen Thomas and Michela Telatin, HIPC - flogging a dead process. The need for a new, independent and just debt work-out for the poorest countries, Jubilee, 2001

Prasad, Rogoff, Wei and Kose 2003

Eswar Prasad, Kenneth Rogoff, Shang-Jin Wei and M. Ayhan Kose, Effects of 
Financial Globalisation on Developing Countries: Some Empirical Evidence, IMF, March 17, 2003

Ravaillon 2003

Martin Ravallion, The Debate on Globalisation, Poverty and Inequality: Why

Measurement Matters, World Bank PRP 3038, April 2003.

Rodrik 2000

Dani Rodrik, How Far Will International Integration Go? Journal of Economic Perspectives, 2000, Vol. 14, no. 1, pp. 177-186

Roustiala 2003

Kal Roustiala, Rethinking the Sovereignty Debate in International Economic

Law, Journal of International Economic Law, 2003, Vol 6(4), pp. 841-878

De la Torre, Yeyati and Schmukler 2002

Augusto de la Torre, Eduardo Levy Yeyati and Sergio L. Schmukler, Financial Globalisation: Unequal Blessings, WB PRWP 2903, Oct. 2002.

Transparency International 2003

Transparency International's Quarterly Newsletter, December 2003, p. 12

United Nations 2003

United Nations, Human Development Report 2003

Wade 2002

Robert Hunter Wade, Globalisation, Poverty and Income Distribution: Does the Liberal Argument Hold? in: D. Gruen, T. O’Brien and J. Lawson (eds.), Globalisation, Living Standards and Inequality. Recent Progress and Continuing Challenges. Proceedings of the RBA Annual Conference, Volume 2002.

Winters 1999

L Alan Winters, Trade and Poverty: Is there a Connection? WTO, Special Report 5, 1999, pp. 43-65

Wolf 2004

Martin Wolf, Why Globalisation Works, New Haven an*d London, Yale University Press, 2004

World Bank 2000

World Bank, World Development Report 2000/2001, Attacking Poverty: 
Opportunity, Empowerment and Security, Washington, 2000

World Bank 2002

World Bank, Globalisation, growth, and poverty, Washington, 2002

World Bank 2003

World Bank, Global Economic Prospects. Realizing the Development Promise of the Doha Agenda, Washington, 2003

WTO 2002

WTO, Annual report 2002, Geneva 